\section{SLAVIC HOLDINGS COMMITTEE REQUESTS RETURN OF QUESTIONNAIRE}

Coincident with the wishes of the Slavic and East European Subsection of the Association of College and Research Libraries of ALA, the Slavic Holdings Committee mailed to academic and public libraries of the U.S. and Canada a questionnaire on holdings of Slavic material in these libraries.

Most libraries promptly returned the completed questionnaires. To the others we have sent two and three reminders with additional copies of the questionnaire. Others have asked for specific information in regard to their particular holdings and their questions have been answered. However, we still have not received all the returns on the questionnaires which have been sent out.

Please help us to succeed 100 percent in our project. Complicated replies are not necessary. Answer the questions as simply as possible and return the forms immediately to: Dr. W. O. Luciw, Chairman, Slavic Holdings Committee, ACRL, State University Library, 418 West Nittany Avenue, University Park, Pennsylvania 16802.

\section{GUIDE TO NEW SLAVIC \\ PUBLICATIONS AVAILABLE}

The Slavic Bibliographic and Documentation Center of the Association of Research Libraries has begun the publication of a monthly acquisitions guide to new Slavic publications. It is designed to provide, in one place, bibliographical information about forthcoming and recent titles in the social sciences and humanities published in all Slavic languages, in the Soviet Union, Poland, Czechoslovakia, Yugoslavia, and Bulgaria. The guide is intended primarily for those college and smaller university libraries which do not collect in depth, lut which do need a good, well-rounded working collection in one or several Slavic languages and/or subject areas.

The first three issues of New Slavic Publications, A Guide to Selection and Acquisition in the Social Sciences and Humanities, have been distributed free of charge. Beginning with vol. 2 , no. 1, September 1970, subscriptions will be accepted at a rate of $\$ 10$ a year for institutions, and $\$ 5$ for individuals. Subscriptions and requests for more information should be addressed to the Slavic Bibliographic and Documentation Center, Association of Research Libraries, 1527 New Hampshire Ave., N.W., Washington, D.C. 20036.

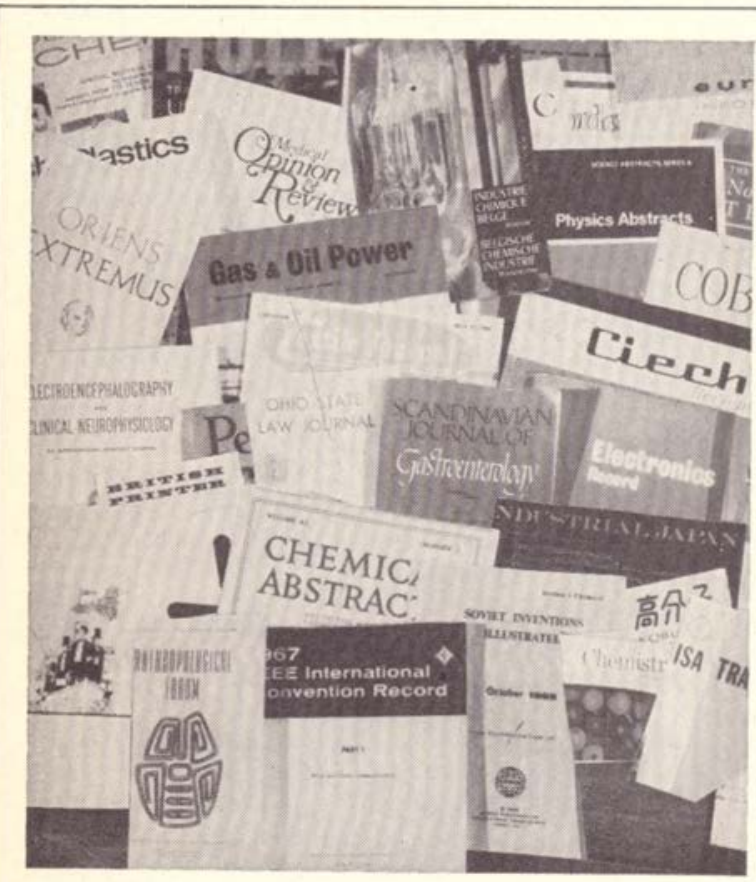

\title{
SERVICE UNSURPASSED
}

The very best serial subscription serv. ice available-decentralized for more personal attention. A superior listing of both domestic and foreign titles.

ERSCO SUBSCRIPTHON SERVICES

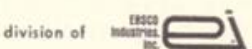

415 Douglas Piaza Bide. Dallas, Teras 75225 (214) $3697591 / 369-7592$ EBsco Builditio. Red Bank, New Jersey 0mo: (201) $741-4300$

P. 0. Box 92901 Los Angeles Californis 90009 Los Angeles, Caind

Room 2.45

Contioeatal Terrace Building 2785 North Speet Boulveard Denver, Colorado 80211 (303) 433.3235

5265 Port Royal Rd. Springfield, Va 22151 (703) 321.7516/321.9630 


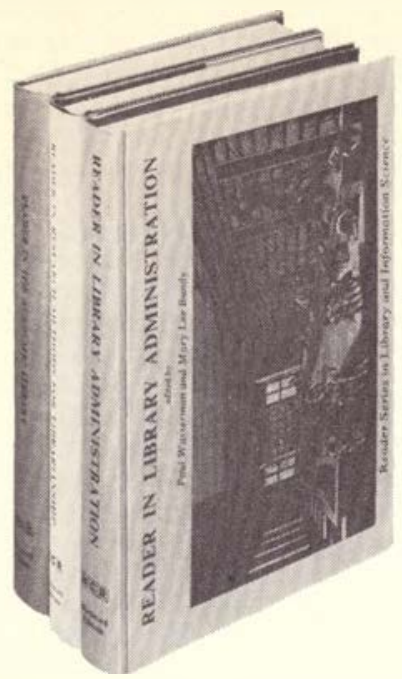

Reader in Library Administration

Edited by Paul Wasserman and Mary Lee Bundy

Designed to provide insight into the organizational dynamics of libraries, this volume includes essays by specialists in library administration as well as by management experts in other fields such as Edward Litchfield, Peter Drucker, Amital Etzioni, and Herbert Simon. Reader in Library Administration focuses upon administrative processes rather than upon techniques and is not intended to provide solutions or formulae. Rather, it shows the complexity of the modern library organization and identifies important issues facing administrations.

$403 \mathrm{pp}$.

hardbound

$\$ 10.95$

\section{Reader in Research Methods for Librarianship}

Edited by Mary Lee Bundy and Paul Wasserman

This volume is concerned not only with the design and conduct of research but also with the philosophical and social implications of research on librarianship. It includes varied academic treatment of research, illustrative examples of research theories, and field accounts as well as samples of actual research instruments. Contributors include distinguished social scientists such as David Riesman, C. Wright Mills, Arthur Vidich, Peter Blau, and William Foote Whyte as well as library specialists in research methods.

$363 \mathrm{pp}$.

hardbound

$\$ 11.95$

\section{Reader in the Academic Library}

Edited by Michael M. Reynolds

The emphasis of the book is to illustrate problems representative of the nature of higher education and of library administration, as opposed to describing operational innovations or giving histories of particular libraries. Among the librarians whose articles appear in the book are Stephen A. McCarthy, Andrew H. Horn, Robert B. Downs, Maurice Tauber, Jesse H. Shera, and Herman H. Fussler. Among those from other fields are Clark Kerr, John D. Millett, Edward C. Banfield, Charles E. Bidwell, Peter Sammartino and Ben Euwema.

$379 p p$.

hardbound

$\$ 10.95$

\section{Reader Series in Library and Information Science}

This series brings together, in convenient volumes, key articles required for a comprehensive view of major topics in library science today. The Reader Series, which is being developed under the direction of Dr. Paul Wasserman, professor at the University of Maryland School of Library and Information Services, includes relevant material from a wide range of disciplines in addition to the traditional literature of librarianship. These volumes are invaluable as ... texts for courses in library science ... supplementary course reading .... a focus for seminar discussion ... the basis for individual study.

\section{NCR MICROCARD EDITIONS} 901 TWENTY-SIXTH STREET, N.W., WASHINGTON, D.C. 20037

Please send me copies of each of the first three volumes of the Reader Series in Library and Information Science at the special price of $\$ 30$ per set, post-paid. Payment must accompany orders at this Special Ratemy check for $\$$ is enclosed.

I prefer to order single volumes as indicated below:

$\square$ Please send me___ copies of Reader in Library Administration at $\$ 10.95$ each ( $\$ 9.95$ if payment is enclosed).

$\square$ Please send me_copies of Reader in Research Methods in Librarianship at $\$ 11.95$ each $(\$ 10.95$ if payment is enclosed).

$\square$ Please send me___ copies of Reader in the Academic Library at $\$ 10.95$ each $(\$ 9.95$ if payment is enclosed).

Payment is enclosed.

Please bill me for the books indicated above plus a small charge for postage and handling.

NAME

TITLE

ORGANIZATION

ADDRESS

CITY

STATE

ZIP

i

Dept. CRL-J 